Article

\title{
Coupling of Bioreaction and Separation via Novel Thermosensitive Ionic Liquids Applied in the Baker's Yeast-Catalyzed Reduction of Ethyl 2-oxo-4-phenylbutyrate
}

\author{
Yuexi Yang, Yugang Shi *, Lifang Feng and Shiyi Tian
}

School of Food Science and Biotechnology, Zhejiang Gongshang University, Hangzhou 310018, China; yyx_526@126.com (Y.Y.); fenglifang@zjgsu.edu.cn (L.F.); tianshiyi@zjgsu.edu.cn (S.T.)

* Correspondence: yugangshi@zjgsu.edu.cn; Tel.: +86-1396-802-1349

Academic Editors: Po-Yu Chen, Jing-Fang Huang and Yen-Ho Chu

Received: 5 April 2020; Accepted: 27 April 2020; Published: 28 April 2020

\begin{abstract}
The use of baker's yeast to reduce ethyl 2-oxo-4-phenylbutyrate (EOPB) in conventional biphasic systems is hindered by low productivities due to mass transfer resistance between the biocatalyst and the substrate partitioned into two different phases. To overcome the limitation, a new reaction-separation coupling process (RSCP) was configured in this study, based on the novel thermosensitive ionic liquids (ILs) with polyoxyethylene-tail. The solubility of ILs in common solvents was investigated to configure the unique thermosensitive ionic liquids-solvent biphasic system (TIBS) in which the reduction was performed. $\left[\left(\mathrm{CH}_{3}\right)_{2} \mathrm{~N}\left(\mathrm{C}_{2} \mathrm{H}_{5}\right)\left(\mathrm{CH}_{2} \mathrm{CH}_{2} \mathrm{O}\right)_{2} \mathrm{H}\right]\left[\mathrm{PF}_{6}\right]\left(\mathrm{c}_{2}\right)$ in 1,2-dimethoxyethane possesses the thermosensitive function of homogeneous at lower temperatures and phase separating at higher temperatures. The phase transformation temperature (PTT) of the mixed system of $c_{2} / 1,2$-dimethoxyethane $(v / v, 5: 18)$ was about $33^{\circ} \mathrm{C}$. The bioreaction takes place in a "homogeneous" liquid phase at $30^{\circ} \mathrm{C}$. At the end of each reduction run, the system temperature is increased upon to the PTT, while $\mathrm{c}_{2}$ is separated from 1,2-dimethoxyethane with turning the system into two phases. The enantiomeric excesses (e.e.) of ethyl (R)-2-hydroxy-4-phenylbutyrate ((R)-EHPB) increased about $25 \sim 30 \%$ and the yield of ethyl-2-hydroxy-4-phenylbutyrate (EHPB) increased $35 \%$ in TIBS, compared with the reduction in 1,2-dimethoxyethane. It is expected that the TIBS established in this study could provide many future opportunities in the biocatalysis.
\end{abstract}

Keywords: thermosensitive ionic liquids-solvent biphasic system; coupled bioreaction and separation; baker's yeast-catalyzed reduction; ethyl 2-oxo-4-phenylbutyrate; ethyl (R)-2-hydroxy-4-phenylbutyrate

\section{Introduction}

The interest in the reaction-separation coupling process (RSCP) has been growing in green chemistry and chemical engineering [1-6], especially in biocatalytic manufacturing processes [7-11]. The RSCP offers an interesting option for equilibrium limited reaction systems by selective removal of one of the products and thereby increasing the product yield [12-16]. It plays an important role in promoting the practical development of biocatalysis. In recent years, the RSCP based on ionic liquids has been used for selective transport of organic compounds [17-22].

Ionic liquids (ILs), especially most of the second generation of air- and water-stable ILs, are increasingly utilized as possible environmentally benign alternative reaction media in biocatalysis in place of conventional solvents [23]. However, the inherently high viscosity of ILs may have unfavorable effects caused by the mass transfer resistance on bioreactions [24-28]. Adding organic cosolvents lowers the viscosity of ILs, but cancels many of the advantages of using ILs [29]. Kong et al. found a temperature-sensitive ionic liquid (IL) that can be employed to the biphasic catalysis system 
(ionic liquid/heptane) possessing the property of "a homogeneous phase under high temperatures, phase separation under low temperatures" [30]. Based on the above findings, the catalyst and the substrate could be in a mono-phase under high temperature to improve reaction efficiency, and the catalyst and the product could be separated and distributed into two different phases, respectively, with the decrease of temperature until a second phase appears. Based on biphasic separation after the monophasic reaction, the problems of contact resistances between catalysts and substrates could be solved. Recently, we have explored a unique novel functionalized ionic liquid, which has been used as a reaction medium to facilitate the enzymatic esterification of FA with lauryl alcohol [31,32]. Moreover, the thermosensitive ILs could also be employed to build a novel biphasic catalysis system to develop to be a new bioreaction-separation coupling technique to improve the efficiency of biotransformation.

It is well noticed that enzyme activity generally depends on the anions of ILs. ILs were then formed with weakly coordinating anions such as $\mathrm{BF}_{4}$ and $\mathrm{PF}_{6}$ that were more air-stable and water-stable. Moreover, the negative effect of hydrogen-bonding on the enzyme activity in the presence of ILs can be associated with the anions effect and their action as hydrogen-bonding acceptors for the protein (lipases). The Hofmeister ion interaction toward protein stabilization is well known in protein sciences [33]. José L. Iborra et al. reported that enzyme activities clearly depend on the nature of the ions, the results were improving as the alkyl chain length of the imidazolium cation increased, and as

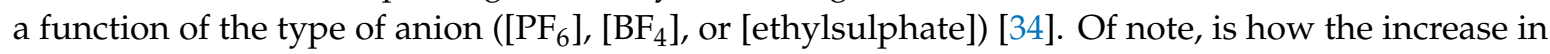
the alkyl chain length of imidazolium cation improves the synthetic activity in all derivatives for ILs based on the $\left[\mathrm{PF}_{6}\right]$ anion, in agreement with previous results obtained for the synthesis of citronellyl esters catalyzed by Novozym 435 [35]. However, for ILs based on the $\left[\mathrm{BF}_{4}\right]$ anion, all the immobilized lipases decreased their activity as the alkyl chain of the imidazolium cation increased. Several authors have described $[\mathrm{Bmim}]\left[\mathrm{PF}_{6}\right]$ as being a more suitable medium than $[\mathrm{Bmim}]\left[\mathrm{BF}_{4}\right]$ for different synthetic reactions catalyzed by the immobilized or aqueous solution of free lipases [36-38]. The low activity displayed by all immobilized lipases in [Emim][MS] agrees with the previously reported effect of most water-miscible ILs to strip essential water molecules from the enzyme microenvironment in anhydrous conditions, producing protein unfolding and deactivation [39-41]. In addition, Itoh et al. reported that both the reaction rate and the enantioselectivity of the reaction depended on the anionic part of ILs $\left(\left[\mathrm{BF}_{4}\right],\left[\mathrm{PF}_{6}\right],\left[\mathrm{SbF}_{6}\right],[\mathrm{OTf}]\right.$, and [TFA] $)$ [42]. They found that hydrophobic IL containing $\left[\mathrm{PF}_{6}\right]$ could act as a favorable solvent in the reaction because lipase was anchored by this IL, and remained in it after the extraction workup of the product due to the insolubility of this IL in both water and extraction of the organic solvent. In addition, as an outstanding example, the fine-tuning of ILs has allowed the design of a lipase-friendly solvent that also enables the dissolution of challenging substrates, such as sugars, cellulose, fatty acids, and triglycerides. Being compatible with enzymes, such as ILs containing a quaternary ammonium structure act as ideal media for enzymatically producing derivatives of many substrates. To achieve this, these enzyme-compatible ILs pertain some common structural features: Multiple ethers and/or hydroxyl groups, to optimize the solvent properties (IL viscosity, H-bond basicity, and water affinity) for mild IL-enzyme interactions [43-45].

Similar to many other whole cell biocatalysis in conventional biphasic systems, the use of baker's yeast to produce enantiomerically pure ethyl (R)-2-hydroxy-4-phenylbutyrate ( $R$ )-EHPB) is hindered by low productivities due to mass transfer resistance between the whole cell biocatalyst with the substrate ethyl 2-oxo-4-phenylbutyrate (EOPB) partitioned into two different phases. In this study, the main aim is to design and synthesize novel quaternary ammonium salts with polyoxyethylene-tail type ILs $\left(b_{n}, c_{n}\right)$ (Scheme 1). In addition, the thermosensitive ionic liquids-solvent biphasic system (TIBS) was configured by using these ILs with the intriguing function of "mono-phase under low temperature, two phases under high temperature". Furthermore, the TIBS was applied to the asymmetric reduction of EOPB with baker's yeast. 


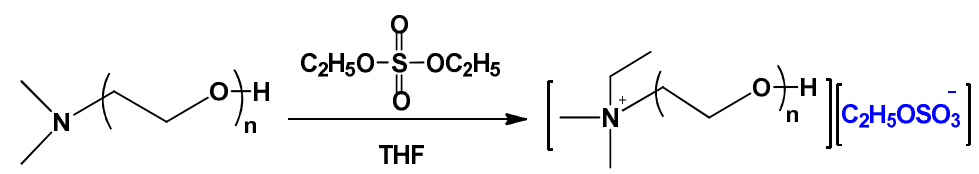

$a_{n}, n=1,2,3$

$b_{n}, n=1,2,3$

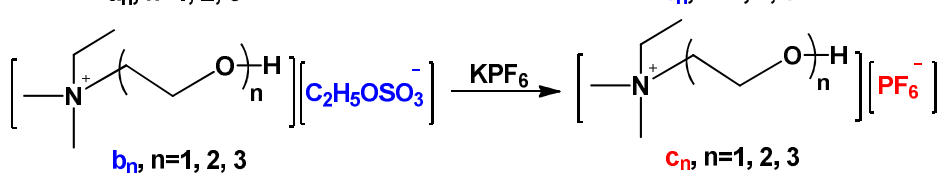

Scheme 1. Synthetic routes to ionic liquids $\left(b_{n}, c_{n}\right)$.

\section{Results and Discussion}

\subsection{Solubilities of the Ionic Liquids (ILs)}

For the construction of a new reaction-separation coupling process (RSCP) with the application of thermosensitive ILs, the primary task is to clear the solubility of these novel ILs in common solvents. As seen from Table 1, the ammonium-based ILs show excellent solubility in strong polar solvents such as water, methanol, and ethanol, while they have poor solubility in nonpolar organic solvents such as nonane, benzene, and petroleum ether at $20{ }^{\circ} \mathrm{C}$. In addition, the solubility of the ILs in 1,2-dimethoxyethane is greatly affected by not only the anion but also the chain length of polyethylene oxide (PEO). As for the ILs with $\mathrm{C}_{2} \mathrm{H}_{5} \mathrm{SO}_{3}{ }^{-}$, only $\mathrm{b}_{1}$ can be soluble in 1,2-dimethoxyethane. However, both $c_{1}$ and $c_{2}$ with the hexafluorophosphate anion $\left(\mathrm{PF}_{6}{ }^{-}\right)$are soluble in 1,2-dimethoxyethane. Moreover, $\mathrm{b}_{2}$ and $\mathrm{c}_{2}$ with the same $\mathrm{PEO}$ chain length show the opposite solubility behavior in 1,2-dimethoxyethane, and the same phenomenon can be observed for $b_{3}$ and $c_{3}$ in acetone, suggesting that the anion plays a crucial role in the solubility of ILs.

Table 1. Solubilities* of the ionic liquids in solvents at $20^{\circ} \mathrm{C}$.

\begin{tabular}{ccccccc}
\hline Solvent & $\mathbf{b}_{\mathbf{1}}$ & $\mathbf{c}_{\mathbf{1}}$ & $\mathbf{b}_{\mathbf{2}}$ & $\mathbf{c}_{\mathbf{2}}$ & $\mathbf{b}_{\mathbf{3}}$ & $\mathbf{c}_{\mathbf{3}}$ \\
\hline water & $\mathrm{s}$ & $\mathrm{s}$ & $\mathrm{s}$ & $\mathrm{s}$ & $\mathrm{s}$ & $\mathrm{s}$ \\
anisole & $\mathrm{i}$ & $\mathrm{i}$ & $\mathrm{i}$ & $\mathrm{i}$ & $\mathrm{i}$ & $\mathrm{i}$ \\
petroleum ether & $\mathrm{i}$ & $\mathrm{i}$ & $\mathrm{i}$ & $\mathrm{i}$ & $\mathrm{i}$ & $\mathrm{i}$ \\
p-xylene & $\mathrm{i}$ & $\mathrm{i}$ & $\mathrm{i}$ & $\mathrm{i}$ & $\mathrm{i}$ & $\mathrm{i}$ \\
diethyl ether & $\mathrm{i}$ & $\mathrm{i}$ & $\mathrm{i}$ & $\mathrm{i}$ & $\mathrm{i}$ & $\mathrm{i}$ \\
methanol & $\mathrm{s}$ & $\mathrm{s}$ & $\mathrm{s}$ & $\mathrm{s}$ & $\mathrm{s}$ & $\mathrm{s}$ \\
ethanol & $\mathrm{s}$ & $\mathrm{s}$ & $\mathrm{s}$ & $\mathrm{s}$ & $\mathrm{s}$ & $\mathrm{s}$ \\
isopropanol & $\mathrm{i}$ & $\mathrm{i}$ & $\mathrm{i}$ & $\mathrm{i}$ & $\mathrm{i}$ & $\mathrm{i}$ \\
2-methoxyethanol & $\mathrm{s}$ & $\mathrm{s}$ & $\mathrm{s}$ & $\mathrm{s}$ & $\mathrm{s}$ & $\mathrm{s}$ \\
1,2-dimethoxyethane & $\mathrm{s}$ & $\mathrm{s}$ & $\mathrm{i}$ & $\mathrm{s}$ & $\mathrm{i}$ & $\mathrm{i}$ \\
nonane & $\mathrm{i}$ & $\mathrm{i}$ & $\mathrm{i}$ & $\mathrm{i}$ & $\mathrm{i}$ & $\mathrm{i}$ \\
benzene & $\mathrm{i}$ & $\mathrm{i}$ & $\mathrm{i}$ & $\mathrm{i}$ & $\mathrm{i}$ & $\mathrm{i}$ \\
acetone & $\mathrm{i}$ & $\mathrm{i}$ & $\mathrm{i}$ & $\mathrm{i}$ & $\mathrm{i}$ & $\mathrm{s}$
\end{tabular}

*s: Solution, i: Insolubilization. b $b_{1}$ : $\left[\left(\mathrm{CH}_{3}\right)_{2} \mathrm{~N}\left(\mathrm{C}_{2} \mathrm{H}_{5}\right) \mathrm{CH}_{2} \mathrm{CH}_{2} \mathrm{OH}\right]\left[\mathrm{C}_{2} \mathrm{H}_{5} \mathrm{SO}_{4}\right], \mathrm{c}_{1}$ : [( $\left.\left(\mathrm{CH}_{3}\right)_{2} \mathrm{~N}\left(\mathrm{C}_{2} \mathrm{H}_{5}\right) \mathrm{CH}_{2} \mathrm{CH}_{2} \mathrm{OH}\right]\left[\mathrm{PF}_{6}\right]$, $\mathrm{b}_{2}$ : $\left[\left(\mathrm{CH}_{3}\right)_{2} \mathrm{~N}\left(\mathrm{C}_{2} \mathrm{H}_{5}\right)\left(\mathrm{CH}_{2} \mathrm{CH}_{2} \mathrm{O}\right)_{2} \mathrm{H}\right]\left[\mathrm{C}_{2} \mathrm{H}_{5} \mathrm{SO}_{4}\right], \mathrm{c}_{2}:\left[\left(\mathrm{CH}_{3}\right)_{2} \mathrm{~N}\left(\mathrm{C}_{2} \mathrm{H}_{5}\right)\left(\mathrm{CH}_{2} \mathrm{CH}_{2} \mathrm{O}\right)_{2} \mathrm{H}\right]\left[\mathrm{PF}_{6}\right], \mathrm{b}_{3}:\left[\left(\mathrm{CH}_{3}\right)_{2} \mathrm{~N}\left(\mathrm{C}_{2} \mathrm{H}_{5}\right)\right.$ $\left.\left(\mathrm{CH}_{2} \mathrm{CH}_{2} \mathrm{O}\right)_{3} \mathrm{H}\right]\left[\mathrm{C}_{2} \mathrm{H}_{5} \mathrm{SO}_{4}\right], \mathrm{c}_{3}:\left[\left(\mathrm{CH}_{3}\right)_{2} \mathrm{~N}\left(\mathrm{C}_{2} \mathrm{H}_{5}\right)\left(\mathrm{CH}_{2} \mathrm{CH}_{2} \mathrm{O}\right)_{3} \mathrm{H}\right]\left[\mathrm{PF}_{6}\right]$.

In order to establish the thermosensitive ionic liquids-solvent biphasic system (TIBS), the solubility of the ILs with various chain lengths of polyethylene oxide (PEO) was investigated at different temperatures in selected organic solvents. With the temperature increase from 25 to $100{ }^{\circ} \mathrm{C}$, there are no changes of solubility of these six ILs $\left(b_{1}, b_{2}, b_{3}, c_{1}, c_{2}, c_{3}\right)$ either in nonpolar organic solvents such as anisole and petroleum ether, or in polar solvents such as methanol and ethanol (Table 2). However, the solubility of $c_{n}$ decreases with the increase of temperature in 1,2-dimethoxyethane. Moreover, it can be inferred that the phase transformation temperature (PTT) of $\mathrm{PF}_{6}{ }^{-}$based ILs $\left(\mathrm{c}_{1}, \mathrm{c}_{2}, \mathrm{c}_{3}\right)$ in 1,2-dimethoxyethane would decrease with the increasing chain length of PEO. 
Table 2. Solubilities of ionic liquids (ILs) modified with different chain lengths of polyethylene oxide in organic solvents under different temperatures.

\begin{tabular}{|c|c|c|c|c|c|c|c|c|c|}
\hline \multirow{2}{*}{ Solvent } & \multicolumn{3}{|c|}{$\mathrm{b}_{1}\left({ }^{\circ} \mathrm{C}\right)$} & \multicolumn{3}{|c|}{$\mathrm{b}_{2}\left({ }^{\circ} \mathrm{C}\right)$} & \multicolumn{3}{|c|}{$\mathrm{b}_{3}\left({ }^{\circ} \mathrm{C}\right)$} \\
\hline & 25 & 50 & 100 & 25 & 50 & 100 & 25 & 50 & 100 \\
\hline anisole & $\mathrm{i}$ & $\mathrm{i}$ & $\mathrm{i}$ & $\mathrm{i}$ & $\mathrm{i}$ & $\mathrm{i}$ & $\mathrm{i}$ & $\mathrm{i}$ & $\mathrm{i}$ \\
\hline petroleum ether & $\mathrm{i}$ & $\mathrm{i}$ & $\mathrm{i}$ & $\mathrm{i}$ & $\mathrm{i}$ & $\mathrm{i}$ & $\mathrm{i}$ & $\mathrm{i}$ & $\mathrm{i}$ \\
\hline 2-methoxyethanol & $\mathrm{s}$ & $\mathrm{s}$ & $\mathrm{s}$ & $\mathrm{s}$ & $\mathrm{s}$ & $\mathrm{s}$ & $\mathrm{s}$ & $\mathrm{s}$ & $\mathrm{s}$ \\
\hline 1,2-dimethoxyethane & $\mathrm{s}$ & $\mathrm{s}$ & $\mathrm{s}$ & $\mathrm{i}$ & $\mathrm{i}$ & $\mathrm{i}$ & $\mathrm{i}$ & $\mathrm{i}$ & $\mathrm{i}$ \\
\hline benzene & $\mathrm{i}$ & $\mathrm{i}$ & $\mathrm{i}$ & $\mathrm{i}$ & $\mathrm{i}$ & $\mathrm{i}$ & $\mathrm{i}$ & $\mathrm{i}$ & $\mathrm{i}$ \\
\hline acetone & $\mathrm{i}$ & $\mathrm{i}$ & $\mathrm{i}$ & $\mathrm{i}$ & $\mathrm{i}$ & $\mathrm{i}$ & $\mathrm{i}$ & $\mathrm{i}$ & $\mathrm{i}$ \\
\hline ethanol & $\mathrm{s}$ & $\mathrm{s}$ & $\mathrm{s}$ & $\mathrm{s}$ & $\mathrm{s}$ & $\mathrm{s}$ & $\mathrm{s}$ & $\mathrm{s}$ & $\mathrm{s}$ \\
\hline methanol & $\mathrm{s}$ & $\mathrm{s}$ & $\mathrm{s}$ & $\mathrm{s}$ & $\mathrm{s}$ & $\mathrm{s}$ & $\mathrm{s}$ & $\mathrm{s}$ & $\mathrm{s}$ \\
\hline \multirow{2}{*}{ Solvent } & \multicolumn{3}{|c|}{$\mathrm{c}_{1}\left({ }^{\circ} \mathrm{C}\right)$} & \multicolumn{3}{|c|}{$\mathrm{c}_{2}\left({ }^{\circ} \mathrm{C}\right)$} & \multicolumn{3}{|c|}{$\mathrm{c}_{3}\left({ }^{\circ} \mathrm{C}\right)$} \\
\hline & 25 & 50 & 100 & 25 & 50 & 100 & 25 & 50 & 100 \\
\hline anisole & $\mathrm{i}$ & $\mathrm{i}$ & $\mathrm{i}$ & $\mathrm{i}$ & $\mathrm{i}$ & $\mathrm{i}$ & $\mathrm{i}$ & $\mathrm{i}$ & $\mathrm{i}$ \\
\hline petroleum ether & $\mathrm{i}$ & $\mathrm{i}$ & $\mathrm{i}$ & $\mathrm{i}$ & $\mathrm{i}$ & $\mathrm{i}$ & $\mathrm{i}$ & $\mathrm{i}$ & $\mathrm{i}$ \\
\hline 2-methoxyethanol & $\mathrm{s}$ & $\mathrm{s}$ & $\mathrm{s}$ & $\mathrm{s}$ & $\mathrm{s}$ & $\mathrm{s}$ & $\mathrm{s}$ & $\mathrm{s}$ & $\mathrm{s}$ \\
\hline 1,2-dimethoxyethane & $\mathrm{s}$ & $\mathrm{s}$ & $\mathrm{i}$ & $\mathrm{s}$ & $\mathrm{i}$ & $\mathrm{i}$ & $\mathrm{i}$ & $\mathrm{i}$ & $\mathrm{i}$ \\
\hline isopropanol & - & - & - & $\mathrm{i}$ & i & $\mathrm{i}$ & $\mathrm{i}$ & $\mathrm{i}$ & $\mathrm{i}$ \\
\hline ethanol & $\mathrm{s}$ & $\mathrm{s}$ & $\mathrm{s}$ & $\mathrm{s}$ & $\mathrm{s}$ & $\mathrm{s}$ & $\mathrm{s}$ & $\mathrm{s}$ & $\mathrm{s}$ \\
\hline methanol & $\mathrm{s}$ & $\mathrm{s}$ & $\mathrm{s}$ & $\mathrm{s}$ & $\mathrm{s}$ & $\mathrm{s}$ & $\mathrm{s}$ & $\mathrm{s}$ & $\mathrm{s}$ \\
\hline
\end{tabular}

*s: Solution, i: Insolubilization. $b_{1}$ : [ $\left.\left(\mathrm{CH}_{3}\right)_{2} \mathrm{~N}\left(\mathrm{C}_{2} \mathrm{H}_{5}\right) \mathrm{CH}_{2} \mathrm{CH}_{2} \mathrm{OH}\right]\left[\mathrm{C}_{2} \mathrm{H}_{5} \mathrm{SO}_{4}\right], \mathrm{c}_{1}$ : [( $\left.\left(\mathrm{CH}_{3}\right)_{2} \mathrm{~N}\left(\mathrm{C}_{2} \mathrm{H}_{5}\right) \mathrm{CH}_{2} \mathrm{CH}_{2} \mathrm{OH}\right]\left[\mathrm{PF}_{6}\right]$, $\mathrm{b}_{2}$ : $\left[\left(\mathrm{CH}_{3}\right)_{2} \mathrm{~N}\left(\mathrm{C}_{2} \mathrm{H}_{5}\right)\left(\mathrm{CH}_{2} \mathrm{CH}_{2} \mathrm{O}\right)_{2} \mathrm{H}\right]\left[\mathrm{C}_{2} \mathrm{H}_{5} \mathrm{SO}_{4}\right], \mathrm{c}_{2}:\left[\left(\mathrm{CH}_{3}\right)_{2} \mathrm{~N}\left(\mathrm{C}_{2} \mathrm{H}_{5}\right)\left(\mathrm{CH}_{2} \mathrm{CH}_{2} \mathrm{O}\right)_{2} \mathrm{H}\right]\left[\mathrm{PF}_{6}\right], \mathrm{b}_{3}:\left[\left(\mathrm{CH}_{3}\right)_{2} \mathrm{~N}\left(\mathrm{C}_{2} \mathrm{H}_{5}\right)\right.$ $\left.\left(\mathrm{CH}_{2} \mathrm{CH}_{2} \mathrm{O}\right)_{3} \mathrm{H}\right]\left[\mathrm{C}_{2} \mathrm{H}_{5} \mathrm{SO}_{4}\right], \mathrm{c}_{3}:\left[\left(\mathrm{CH}_{3}\right)_{2} \mathrm{~N}\left(\mathrm{C}_{2} \mathrm{H}_{5}\right)\left(\mathrm{CH}_{2} \mathrm{CH}_{2} \mathrm{O}\right)_{3} \mathrm{H}\right]\left[\mathrm{PF}_{6}\right]$.

\subsection{Phase Transformation Temperature of $c_{2} / 1,2$-Dimethoxyethane Biphasic Systems}

As shown in Table 3, the mixture of $\left[\left(\mathrm{CH}_{3}\right)_{2} \mathrm{~N}\left(\mathrm{C}_{2} \mathrm{H}_{5}\right)\left(\mathrm{CH}_{2} \mathrm{CH}_{2} \mathrm{O}\right)_{2} \mathrm{H}\right]\left[\mathrm{PF}_{6}\right]\left(\mathrm{c}_{2}\right)$ and 1,2-dimethoxyethane show a "homogeneous" liquid phase at $20^{\circ} \mathrm{C}$. $\mathrm{c}_{2}$ was precipitated from 1,2-dimethoxyethane $(v / v$, 1:1) with the increase of the system temperature to $57^{\circ} \mathrm{C}$, leading to the system separation into two phases. The $c_{2}$ in 1,2-dimethoxyethane possesses the thermosensitive function of "mono-phase under low temperature, separation of the system into two phases under high temperature". Moreover, the phase transformation temperature (PTT) of the biphasic system decreases with the volume of 1,2-dimethoxyethane increase. The PTT of the biphasic system decreases to $26^{\circ} \mathrm{C}$ when the volume ratio of 1,2-dimethoxyethane to water is up to 4:1.

Table 3. Effect of 1,2-dimethoxyethane volume on the phase transformation temperature (PTT) of $\mathrm{c}_{2} / 1$,2-dimethoxyethane biphasic systems.

\begin{tabular}{cccc}
\hline $\mathbf{c}_{\mathbf{2}}(\mathbf{m L})$ & $\mathbf{1 , 2}$-Dimethoxyethane $(\mathbf{m L})$ & $\mathbf{2 0}{ }^{\circ} \mathbf{C}$ & PTT $\left({ }^{\circ} \mathbf{C}\right)$ \\
\hline 0.1 & 0.1 & homogeneous phase & 57.0 \\
0.1 & 0.2 & homogeneous phase & 50.0 \\
0.1 & 0.3 & homogeneous phase & 47.5 \\
0.1 & 0.4 & homogeneous phase & 26.0 \\
\hline
\end{tabular}

2.3. Asymmetric Reduction of Ethyl 2-oxo-4-phenylbutyrate (EOPB) in Thermosensitive Ionic Liquids-Solvent Biphasic System (TIBS)

ILs as (co-)solvents can modulate enzymatic activity by improving substrate specificity, affinity, and enantioselectivity, increasing substrate solubility, and therefore they can be employed to enzymatic reactions. The modulation of activity is caused by a complex combination of effects, differing for each reaction system. The enzyme activity, stability, and enantioselectivity in the ILs media is closely associated with variants of the molecular structure of the ion pairs and enzymes $[46,47]$. The biocompatibility of $c_{2}$ should be assessed before application as a bioreaction medium. To evaluate 
the effectiveness of $c_{2}$ on the asymmetric reduction of ethyl 2-oxo-4-phenylbutyrate (EOPB) with baker's yeast, the conversion ratio (conv.) of EOPB, yield of ethyl 2-hydroxy-4-phenylbutyrate (EHPB), and enantiomeric excesses of ethyl $(R)$-EHPB (e.e. $(R))$ were measured in the presence of a various initial concentration of $c_{2}(\leq 0.1 \%, v / v)$. As shown in Figure 1 , at the initial concentration of $0.05 \% c_{2}$ in the benzene-water biphasic system, the e.e. of (R)-EHPB increases to $94.4 \%$ and the conversion of EOPB and yield of EHPB reach to the top value. Compared with 1-butyl-3-methylimidazolium hexafluorophosphate $\left([\mathrm{BMIM}]\left[\mathrm{PF}_{6}\right]\right), \mathrm{c}_{2}$ is a more biocompatible alternative to the biocatalytic reaction at the same conditions. With the increase of the initial concentration of $\mathrm{c}_{2}$ from $0.03 \%$ to $0.10 \%(v / v)$, the e.e. of (R)-EHPB, conversion of EOPB, and yield of EHPB show no significant changes $(p>0.05)$. Compared with a biphasic system containing $[\mathrm{BMIM}]\left[\mathrm{PF}_{6}\right]$, the e.e. of $(R)-\mathrm{EHPB}$, conversion of EOPB, and yield of EHPB is significantly higher $(p<0.05)$ in the biphasic system containing $C_{2}$ with initial concentration from $0.04 \%$ to $0.10 \%$. Of note, is how the combination of quaternary ammonium cation with multiple ether and/or hydroxyl groups improves the enzymatically synthetic activity for ILs based on the $\left[\mathrm{PF}_{6}\right]$ anion, in agreement with previous results obtained for CAL-B-catalyzing the synthesis with the design of a lipase-friendly solvent that also enables the dissolution of challenging substrates, such as sugars, fatty acids, and triglycerides [43-45].

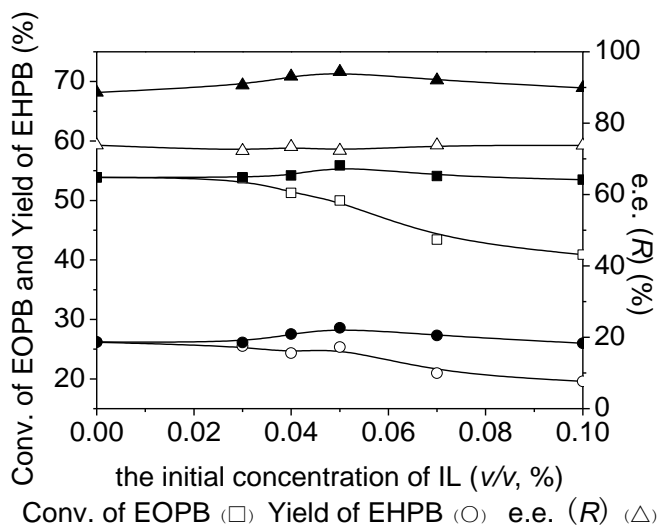

Figure 1. Comparison of biocompatibility of $\mathrm{c}_{2}$ and $[\mathrm{BMIM}]\left[\mathrm{PF}_{6}\right]$ as an additive for the reaction in the benzene-water biphasic system. An amount of $2.00 \mathrm{~g}$ baker's yeast, $0.0825 \mathrm{~g}$ EOPB, $20.0 \mathrm{~mL}$ benzene, $10.0 \mathrm{~mL}$ water, $30^{\circ} \mathrm{C}, 200 \mathrm{rpm}, 5 \mathrm{~h}$. Solid point $-\mathrm{c}_{2}$; hollow point-[BMIM][PF 6$]$.

The phase transformation temperature (PTT) of the $c_{2} / 1,2$-dimethoxyethane biphasic system $(v / v$, 5:18) is about $33^{\circ} \mathrm{C}$. Therefore, the asymmetric reduction of EOPB was performed at $30^{\circ} \mathrm{C}$, for ensuring that the bioreaction takes place in a "homogeneous" liquid phase. At the end of each reduction run, the system temperature was increased upon to $33^{\circ} \mathrm{C}$ and $c_{2}$ was precipitated from 1,2-dimethoxyethane. As shown in Figure 2, the e.e. of $(R)$-EHPB was enhanced about $25 \sim 30 \%$ and the conversion of EOPB and yield of EHPB were significantly higher $(p<0.05)$ in the $c_{2} / 1,2$-dimethoxyethane $(v / v, 5: 18)$ biphasic system, compared with the reduction in 1,2-dimethoxyethane. Obviously, the existence of $c_{2} / 1,2$-dimethoxyethane with the temperature-dependent phase separation property provides fundamental support of the reaction-separation coupling process (RSCP). Moreover, the biocatalyst in the ILs phase can be separated and recycled by a simple phase separation. 


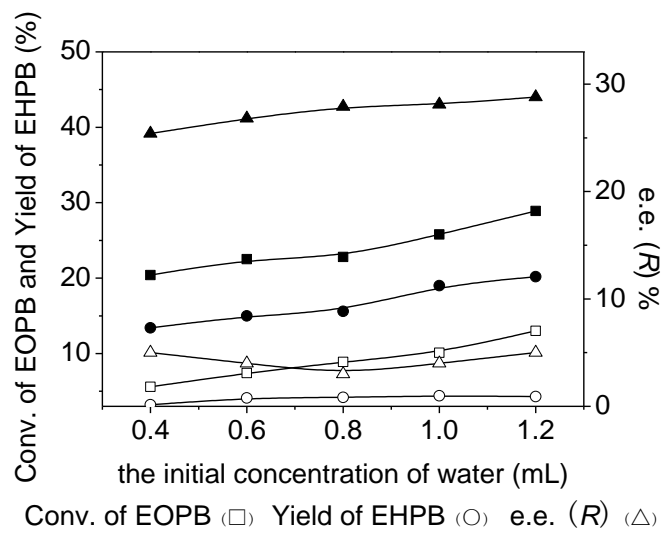

Figure 2. Effect of the initial concentration of water on the reaction by baker's yeast. An amount of $3.00 \mathrm{~g}$ baker's yeast, $0.165 \mathrm{~g}$ EOPB, $5.0 \mathrm{~mL} \mathrm{c}_{2}, 18.0 \mathrm{~mL} \mathrm{1,2-dimethoxyethane,} 30^{\circ} \mathrm{C}, 24 \mathrm{~h}$. Solid point-in the $c_{2} / 1,2$-dimethoxyethane biphasic system; hollow point-in 1,2-dimethoxyethane.

Baker's yeast pretreated by PC was employed to reduce 2-oxo-4-phenylbutyrate (EOPB) in the thermosensitive $c_{2} / 1,2$-dimethoxyethane biphasic system $(v / v, 5: 18)$, compared with the reduction using baker's yeast without pretreatment by PC at the same conditions (Figure 3). The reduction activity of baker's yeast and the enantioselectivity of the reduction were improved by employing the baker's yeast pretreated with alpha-phenacyl chloride (PC) [48]. With the introduction of pretreated baker's yeast to the reduction, the enantioselectivity of the reduction of EOPB was improved and shifted towards forming the desired configuration (48.3\%, e.e. (R)-EHPB). Moreover, the conversion ratio (conv.) of EOPB and the yield of EHPB were significantly increased by $9 \%$, respectively, compared with the use of unpretreated baker's yeast.

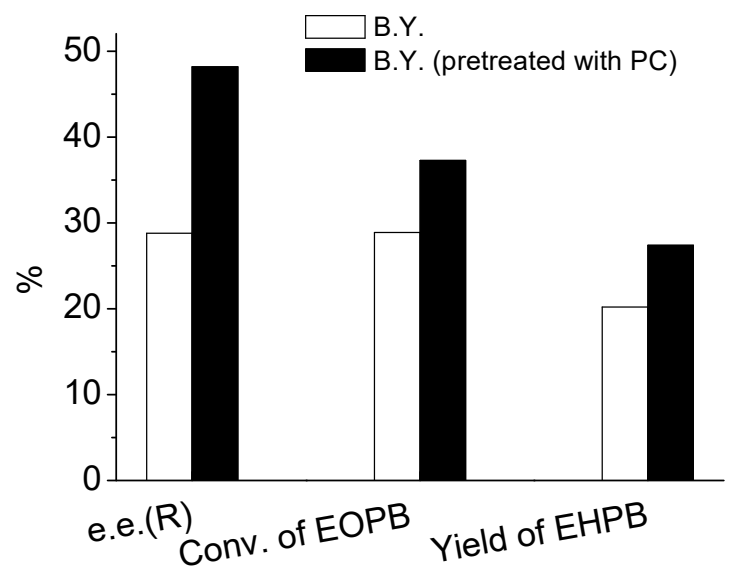

Figure 3. The reduction of ethyl 2-oxo-4-phenylbutyrate (EOPB) catalyzed by baker's yeast pretreated with alpha-phenacyl chloride (PC) in the thermosensitive $c_{2} / 1,2$-dimethoxyethane biphasic system. An amount of $3.00 \mathrm{~g}$ pretreated baker's yeast, $0.165 \mathrm{~g} \mathrm{EOPB}, 1.2 \mathrm{~mL} \mathrm{H}{ }_{2} \mathrm{O}, 5.0 \mathrm{~mL} \mathrm{c}, 18.0 \mathrm{~mL}$ 1,2-dimethoxyethane, $30^{\circ} \mathrm{C}, 24 \mathrm{~h}$.

\section{Materials and Methods}

\subsection{Materials}

Anisole $\left(\mathrm{CH}_{3} \mathrm{OC}_{6} \mathrm{H}_{5}, 99.7 \%\right)$, petroleum ether (ACS reagent), p-xylene $\left.\left(\mathrm{C}_{6} \mathrm{H}_{4}\left(\mathrm{CH}_{3}\right)_{2}\right), \geq 99.7 \%\right)$, diethyl ether $\left(\left(\mathrm{C}_{2} \mathrm{H}_{5}\right)_{2} \mathrm{O}\right.$ ACS reagent), methanol $\left(\mathrm{CH}_{3} \mathrm{OH}, \geq 99.9 \%\right)$, ethanol $\left(\mathrm{CH}_{3} \mathrm{CH}_{2} \mathrm{OH}\right.$, $\geq 99.9 \%)$, isopropanol $\left(\left(\mathrm{CH}_{3}\right)_{2} \mathrm{CHOH}, \geq 99.7 \%\right)$, 2-methoxyethanol $\left(\mathrm{CH}_{3} \mathrm{OCH}_{2} \mathrm{CH}_{2} \mathrm{OH}, \geq 99.9 \%\right)$, 1,2-dimethoxyethane $\left(\mathrm{CH}_{3} \mathrm{OCH}_{2} \mathrm{CH}_{2} \mathrm{OCH}_{3}, 99.9 \%\right)$, nonane $\left(\mathrm{CH}_{3}\left(\mathrm{CH}_{2}\right)_{7} \mathrm{CH}_{3}, \geq 99 \%\right)$, benzene $\left(\mathrm{C}_{6} \mathrm{H}_{6}, \geq 99.7 \%\right)$, acetone $\left(\mathrm{CH}_{3} \mathrm{COCH}_{3}, \geq 99.9 \%\right)$, anhydrous sodium acetate $\left(\mathrm{CH}_{3} \mathrm{COONa},>99 \%\right)$, 
ethylene oxide (EO, $\mathrm{C}_{2} \mathrm{H}_{4} \mathrm{O} \geq 99.5 \%$ ), $\mathrm{N}, \mathrm{N}$-dimethylethanolamine (DMEA, $\left(\mathrm{CH}_{3}\right)_{2} \mathrm{NCH}_{2} \mathrm{CH}_{2} \mathrm{OH}$, $\mathrm{a}_{1}$ ), tetrahydrofuran (THF, $\left(\mathrm{CH}_{2}\right)_{4} \mathrm{O}, \geq 99.5 \%$ ), diethyl sulfate $\left(\mathrm{C}_{4} \mathrm{H}_{10} \mathrm{O}_{4} \mathrm{~S}, 98 \%\right)$, potassium hexafluorophosphate $\left(\mathrm{KPF}_{6}, \geq 99 \%\right)$, diethyl ether anhydrous $\left(\mathrm{C}_{4} \mathrm{H}_{10} \mathrm{O}, \geq 99 \%\right)$, potassium bromide $(\mathrm{KBr}$, FT-IR grade) were purchased from Sigma-Aldrich (Shanghai, China). Unless otherwise stated, all other reagents used were of analytical grade. Ultrapure water produced by an Aquapro purification system $(18.2 \mathrm{M} \Omega \mathrm{cm}$, Aquapro International Co., Ltd., Dover, DE, USA) was used throughout the experiments.

\subsection{Preparation of the Ionic Liquid Precursors $\left(a_{2}-a_{4}\right)$}

An amount of $100 \mathrm{~mL} \mathrm{~N}, \mathrm{~N}$-dimethylethanolamine $\left(\mathrm{a}_{1}\right)$, and $0.4 \mathrm{~g}$ anhydrous sodium acetate $\left(\mathrm{CH}_{3} \mathrm{COONa}\right)$ were added to a $500 \mathrm{~mL}$ stainless-steel high-pressure reactor fitted with temperature controlling apparatus and a mechanical stirrer. The reactor is purged three times with $\mathrm{N}_{2}$. The temperature of the reactor which maintained the mixture was raised to $80^{\circ} \mathrm{C}$, and kept at that temperature as $80 \mathrm{~mL}$ ethylene oxide (EO) was gradually introduced to the stirred reaction mixture under the pressure below $0.1 \mathrm{MPa}$. Then, the reaction was continued for 30 min under $0.2 \mathrm{MPa}$. The ethoxylation products were separated and purified by distillation $\left(75 \sim 142{ }^{\circ} \mathrm{C}\right)$ to give $43.37 \mathrm{~g}$ of $\mathrm{a}_{2}$ (collected at $75 \sim 77^{\circ} \mathrm{C}, 97 \%$ purity degree, GC), $38.38 \mathrm{~g}$ of $\mathrm{a}_{3}$ (collected at $105 \sim 107^{\circ} \mathrm{C}, 96 \%$ purity degree, GC), and $31.50 \mathrm{~g}$ of $\mathrm{a}_{4}$ (collected at $140 \sim 142{ }^{\circ} \mathrm{C}, 94 \%$ purity degree, GC). Distillation conditions: $\varnothing 15 \times 350 \mathrm{~mm}$ packed column, high-performance stainless-steel triangular wire spring fillers, $200 \mathrm{~mm}$ filling height, reflux ratio $\mathrm{R}>10,1 \mathrm{mmHg}$ vacuum degree. The ethoxylation procedure is shown in Figure 4.

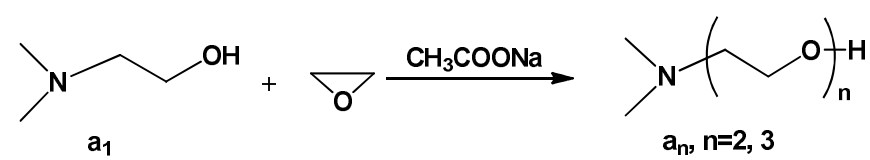

Figure 4. The synthesis route to $a_{n}$.

The purified ethoxylation products were confirmed by a nuclear magnetic resonance spectrometer (NMR, Bruker Avance III, Billerica, USA), a gas chromatography (GC, Agilent 6890, Santa Clara, USA), an electron spray ionization mass spectrometry (ESI-MS, Agilent 6220, Santa Clara, USA), and a Fourier transform infrared spectrometer (FT-IR, Nicolet iS5, Thermo Fisher, USA). ESI-MS: $m / z 134.4$ $\left[\mathrm{a}_{2}+\mathrm{H}\right]^{+}, 178.4\left[\mathrm{a}_{3}+\mathrm{H}\right]^{+}, 222.4\left[\mathrm{a}_{4}+\mathrm{H}\right]^{+} ; \mathrm{m} / z 200.3\left[\mathrm{a}_{3}+\mathrm{Na}\right]^{+}, 244.4\left[\mathrm{a}_{4}+\mathrm{Na}\right]^{+} .{ }^{1} \mathrm{H}-\mathrm{NMR}(250 \mathrm{mHz}$, $\left.\mathrm{D}_{2} \mathrm{O}\right)$ of $\mathrm{a}_{2}: \delta=2.11\left(6 \mathrm{H}, 2 \times \mathrm{CH}_{3}\right), \delta=2.45\left(2 \mathrm{H}, \mathrm{CH}_{2} \mathrm{CH}_{2} \mathrm{O}\right), \delta=3.52\left(4 \mathrm{H}, \mathrm{CH}_{2} \mathrm{CH}_{2} \mathrm{OH}\right), \delta=3.60$ $\left(2 \mathrm{H}, \mathrm{CH}_{2} \mathrm{CH}_{2} \mathrm{O}\right) .{ }^{1} \mathrm{H}-\mathrm{NMR}\left(250 \mathrm{mHz}, \mathrm{D}_{2} \mathrm{O}\right)$ of $\mathrm{a}_{3}: \delta=2.23\left(6 \mathrm{H}, 2 \times \mathrm{CH}_{3}\right), \delta=2.49\left(2 \mathrm{H}, \mathrm{CH}_{2} \mathrm{CH}_{2} \mathrm{O}\right)$, $\delta=3.47-3.65\left(12 \mathrm{H}, \mathrm{CH}_{2} \mathrm{CH}_{2} \mathrm{O}\right) .{ }^{1} \mathrm{H}-\mathrm{NMR}\left(250 \mathrm{mHz}, \mathrm{D}_{2} \mathrm{O}\right)$ of $\mathrm{a}_{4}: \delta=2.18\left(6 \mathrm{H}, 2 \times \mathrm{CH}_{3}\right), \delta=2.44(2 \mathrm{H}$, $\left.\mathrm{CH}_{2} \mathrm{CH}_{2} \mathrm{O}\right), \delta=3.46-3.62\left(16 \mathrm{H}, \mathrm{CH}_{2} \mathrm{CH}_{2} \mathrm{O}\right)$.

For the FT-IR spectra measurements, the diffuse reflectance technique was utilized in the range from 4000 to $400 \mathrm{~cm}^{-1}$. The samples were ground with a FT-IR grade potassium bromide (KBr) powder and then pressed into $1 \mathrm{~mm}$ pellets. The strong absorbance at $1120 \mathrm{~cm}^{-1}$ confirmed the formation of ether linkage (-C-O-C-). It is also noticed that the relative peak intensity and peak width of this band were enhanced with the increase of polyether chain length in the molecular structure of EO-derivatives, compared with $\mathrm{a}_{1}$ (Figure 5A). Additionally, the evidence of the stronger absorbance at $2960 \sim 2825 \mathrm{~cm}^{-1}$ for the $\mathrm{C}-\mathrm{H}$ stretching feature (of $-\mathrm{CH}_{2},-\mathrm{CH}_{3}$ ) implied the successful introduction of the poly (EO) chains (Figure 5B).

From the above results, it can be seen that the poly (EO) chains were connected to the $\mathrm{OH}$ group from DMEA. The difference between DMEA $\left(a_{1}\right)$ and its EO-derivatives $\left(a_{2}, a_{3} a_{4}\right)$ is the difference in the polyether chain length. 

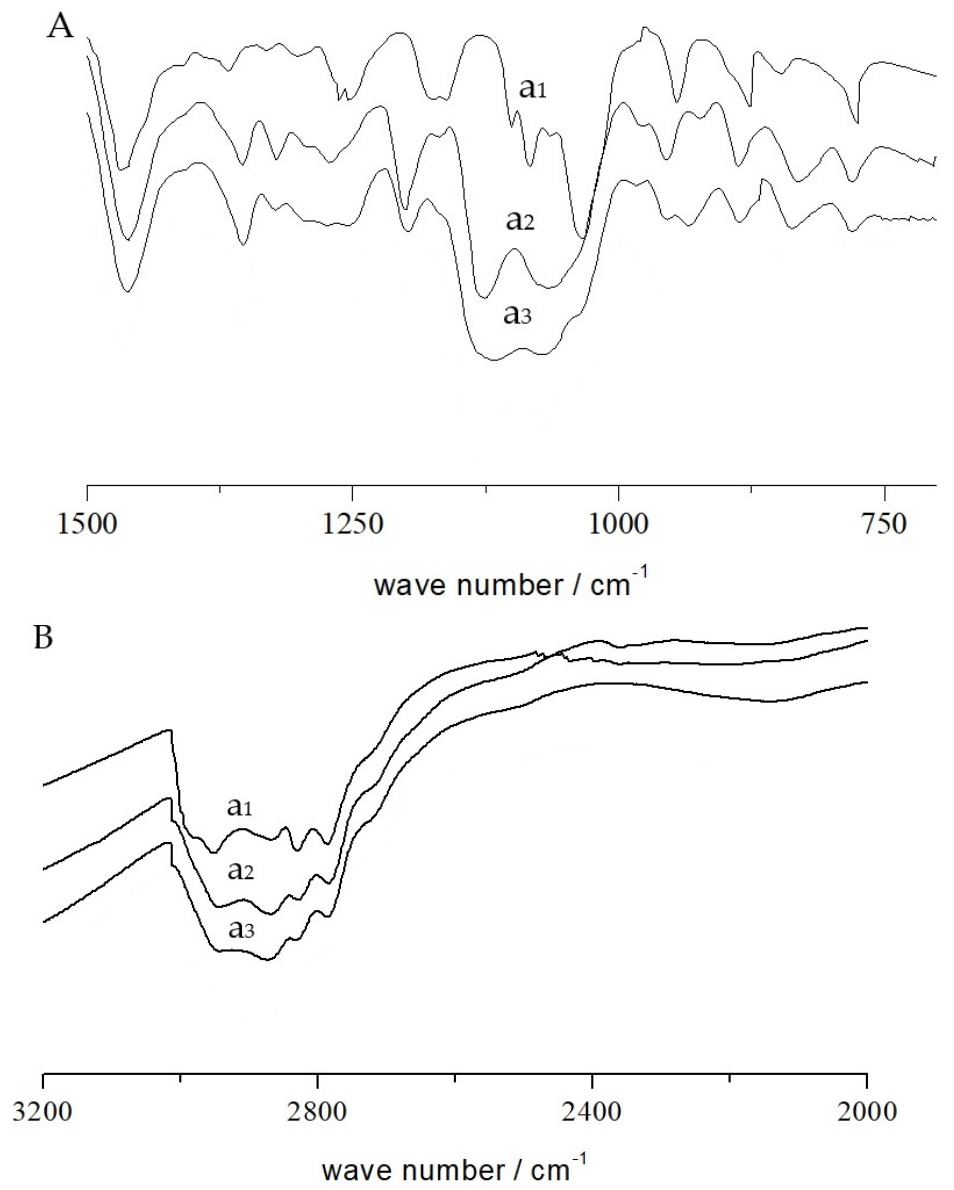

Figure 5. Fourier transform infrared (FT-IR) spectra of $N, N$-dimethylethanolamine (DMEA, $\mathrm{a}_{1}$ ), $\mathrm{a}_{2}\left(\left(\mathrm{CH}_{3}\right)_{2} \mathrm{~N}\left(\mathrm{CH}_{2} \mathrm{CH}_{2} \mathrm{O}\right)_{2} \mathrm{H}\right)$, and $\mathrm{a}_{3}\left(\left(\mathrm{CH}_{3}\right)_{2} \mathrm{~N}\left(\mathrm{CH}_{2} \mathrm{CH}_{2} \mathrm{O}\right)_{3} \mathrm{H}\right)$. (A) FT-IR spectra in the wavenumber range from 1500 750 $\mathrm{cm}^{-1}$; (B) FT-IR spectra in the wavenumber range from $3200 \sim 2000 \mathrm{~cm}^{-1}$.

\subsection{Preparation of the Ionic Liquid $\left(b_{1} \sim b_{3}, c_{1} \sim c_{3}\right)$}

The synthetic routes to $b_{1} \sim b_{4}, c_{1} \sim c_{3}$ are shown in Scheme 1. Products were confirmed by a nuclear magnetic resonance spectrometer (NMR, Bruker Avance III, Billerica, USA), a gas chromatography (GC, Agilent 6890, Santa Clara, USA), and a Fourier transform infrared spectrometer (FT-IR, Nicolet iS5, Thermo Fisher, USA).

$\mathrm{b}_{1}: 18.0 \mathrm{~g} \mathrm{a}_{1}(0.2 \mathrm{~mol})$ and $100 \mathrm{~mL}$ tetrahydrofuran (THF) were placed in a $500 \mathrm{~mL}$ three-mouth flask. The reactor was purged three times with $\mathrm{N}_{2}$. An amount of $30.9 \mathrm{~g}$ diethyl sulfate $(0.2 \mathrm{~mol})$ was dropped slowly into the flask at $20^{\circ} \mathrm{C}$. The reaction was carried out under reflux for $48 \mathrm{~h}$. The organic solvent was removed under a vacuum and the product was dried under a vacuum $\left(4 \mathrm{mmHg}, 60^{\circ} \mathrm{C}\right)$ for $12 \mathrm{~h}$ to a viscous transparent oil and weighed $\left(47.81 \mathrm{~g}, 98.3 \%\right.$ yield). FT-IR $\left(\mathrm{KBr}, \mathrm{cm}^{-1}\right): 3405 \vee(\mathrm{O}-\mathrm{H})$; 2907, $2980 \vee\left(-\mathrm{CH}_{3}\right), v\left(-\mathrm{CH}_{2}\right) ; 1481 \delta$ as $\left(\mathrm{CH}_{3}\right), \delta\left(\mathrm{CH}_{2}\right) ; 1224 \vee$ as $\left(\mathrm{OSO}_{3}{ }^{-}\right) ; 1068,1017 \vee\left(\mathrm{N}-\mathrm{CH}_{3}\right)$, $v\left(\mathrm{~N}-\mathrm{CH}_{2}\right) ; 918 v$ as $(\mathrm{C}-\mathrm{O}-\mathrm{S})$.

The synthesis methods of $b_{2}, b_{3}$, and $b_{4}$ are similar to those of $b_{1} . b_{2}: 7.3 \mathrm{~g} \mathrm{a} 2,50 \mathrm{~mL}$ tetrahydrofuran (THF), $8.45 \mathrm{~g}$ diethyl sulfate $(54.8 \mathrm{mmol})$. The product was dried under a vacuum $\left(4 \mathrm{mmHg}, 60^{\circ} \mathrm{C}\right)$ for $12 \mathrm{~h}$ and weighed (14.14 g, 89.8\% yield). $\mathrm{b}_{3}: 17.7 \mathrm{~g} \mathrm{a}_{3}, 50 \mathrm{~mL}$ THF, $15.4 \mathrm{~g}$ diethyl sulfate (100 mmol). The product was dried under a vacuum $\left(4 \mathrm{mmHg}, 60^{\circ} \mathrm{C}\right)$ for $10 \mathrm{~h}$ and weighed $(29.65 \mathrm{~g}, 89.5 \%$ yield). $\mathrm{b}_{4}: 12.5 \mathrm{~g} \mathrm{a}_{3}, 50 \mathrm{~mL}$ THF, $10.9 \mathrm{~g}$ diethyl sulfate $(70.7 \mathrm{mmol})$. The product was dried under a vacuum $\left(4 \mathrm{mmHg}, 60^{\circ} \mathrm{C}\right)$ for $10 \mathrm{~h}$ and weighed $\left(19.46 \mathrm{~g}, 83.2 \%\right.$ yield). ${ }^{1} \mathrm{H}-\mathrm{NMR}\left(250 \mathrm{mHz}, \mathrm{D}_{2} \mathrm{O}\right)$ of $\mathrm{b}_{2}: \delta=1.15$ $\left(3 \mathrm{H}, \mathrm{CH}_{2} \mathrm{CH}_{3}\right), \delta=2.88\left(6 \mathrm{H}, 2 \times \mathrm{CH}_{3}\right), \delta=3.23\left(4 \mathrm{H}, \mathrm{CH}_{2} \mathrm{CH}_{2} \mathrm{OH}\right), \delta=3.32\left(2 \mathrm{H}, \mathrm{CH}_{2} \mathrm{CH}_{3}\right), \delta=3.43$ $\left(2 \mathrm{H}, \mathrm{CH}_{2} \mathrm{CH}_{2} \mathrm{O}\right), \delta=3.50\left(2 \mathrm{H}, \mathrm{CH}_{2} \mathrm{CH}_{2} \mathrm{O}\right) .{ }^{1} \mathrm{H}-\mathrm{NMR}\left(250 \mathrm{mHz}, \mathrm{D}_{2} \mathrm{O}\right)$ of $\mathrm{b}_{3}: \delta=1.15\left(3 \mathrm{H}, \mathrm{CH}_{2} \mathrm{CH}_{3}\right)$, 
$\delta=3.19\left(6 \mathrm{H}, 2 \times \mathrm{CH}_{3}\right), \delta=3.22-3.69\left(14 \mathrm{H}, \mathrm{CH}_{2} \mathrm{CH}_{3}, \mathrm{CH}_{2} \mathrm{CH}_{2} \mathrm{O}\right), \delta=3.87\left(2 \mathrm{H}, \mathrm{CH}_{2} \mathrm{CH}_{2} \mathrm{O}\right), \delta=3.93(2 \mathrm{H}$, $\mathrm{CH}_{2} \mathrm{CH}_{2} \mathrm{O}$ ).

$\mathrm{c}_{1}: 10.11 \mathrm{~g} \mathrm{~b}, 50 \mathrm{~mL}$ tetrahydrofuran (THF), and $7.65 \mathrm{~g}$ potassium hexafluorophosphate were added to a $100 \mathrm{~mL}$ three-mouth flask fitted. The mixture was stirred for $48 \mathrm{~h}$ under a nitrogen atmosphere at $20^{\circ} \mathrm{C}$. After filtration, the solvent was removed under a vacuum and the product was dried under a vacuum $\left(4 \mathrm{mmHg}, 80^{\circ} \mathrm{C}\right)$ for $12 \mathrm{~h}$ to give a viscous transparent oil. $\mathrm{IR}\left(\mathrm{KBr}, \mathrm{cm}^{-1}\right): 3602 \mathrm{v}$ $(\mathrm{O}-\mathrm{H}) ; 3359 \vee(\mathrm{O}-\mathrm{H}) ; 2913,2989,3062 \vee\left(-\mathrm{CH}_{3}\right), v\left(-\mathrm{CH}_{2}\right) ; 1484 \delta$ as $\left(-\mathrm{CH}_{3}\right) ; 1473 \delta\left(-\mathrm{CH}_{2}\right) ; 841 v(\mathrm{P}-\mathrm{F})$; $558 \delta(\mathrm{P}-\mathrm{F})$. The synthesis methods of $\mathrm{c}_{2}$ and $\mathrm{c}_{3}$ were similar to those of $\mathrm{c}_{1} . \mathrm{c}_{2}: 14.14 \mathrm{~g} \mathrm{~b}_{2}, 50 \mathrm{~mL}$ THF, and 10.15 g potassium hexafluorophosphate. ${ }^{1} \mathrm{H}-\mathrm{NMR}\left(250 \mathrm{mHz}, \mathrm{D}_{2} \mathrm{O}\right)$ of $\mathrm{c}_{2}: \delta=1.17\left(3 \mathrm{H}, \mathrm{CH}_{2} \mathrm{CH}_{3}\right)$, $\delta=2.92\left(6 \mathrm{H}, 2 \times \mathrm{CH}_{3}\right), \delta=3.27\left(4 \mathrm{H}, \mathrm{CH}_{2} \mathrm{CH}_{2} \mathrm{OH}\right), \delta=3.36\left(2 \mathrm{H}, \mathrm{CH}_{2} \mathrm{CH}_{3}\right), \delta=3.45\left(2 \mathrm{H}, \mathrm{CH}_{2} \mathrm{CH}_{2} \mathrm{O}\right)$, $\delta=3.54\left(2 \mathrm{H}, \mathrm{CH}_{2} \mathrm{CH}_{2} \mathrm{O}\right) . \mathrm{c}_{3}: 14.51 \mathrm{~g} \mathrm{~b}_{3}, 60 \mathrm{~mL} \mathrm{THF}$, and $8.07 \mathrm{~g}$ potassium hexafluorophosphate. ${ }^{1} \mathrm{H}-\mathrm{NMR}\left(250 \mathrm{mHz}, \mathrm{D}_{2} \mathrm{O}\right)$ of $\mathrm{c}_{3}: \delta=1.17\left(3 \mathrm{H}, \mathrm{CH}_{2} \mathrm{CH}_{3}\right), \delta=3.21\left(6 \mathrm{H}, 2 \times \mathrm{CH}_{3}\right), \delta=3.27-3.71(14 \mathrm{H}$, $\left.\mathrm{CH}_{2} \mathrm{CH}_{3}, \mathrm{CH}_{2} \mathrm{CH}_{2} \mathrm{O}\right), \delta=3.89\left(2 \mathrm{H}, \mathrm{CH}_{2} \mathrm{CH}_{2} \mathrm{O}\right), \delta=4.01\left(2 \mathrm{H}, \mathrm{CH}_{2} \mathrm{CH}_{2} \mathrm{O}\right)$.

\subsection{Bioreduction}

An amount of $0.165 \mathrm{~g}$ ethyl 2-oxo-4-phenylbutyrate (EOPB), $1.2 \mathrm{~mL} \mathrm{H}_{2} \mathrm{O}, 5 \mathrm{~mL} \mathrm{c}_{2}$, and $18 \mathrm{~mL}$ 1,2-dimethoxyethane were well mixed. Then, the reduction was proceeded at $30^{\circ} \mathrm{C}$ with stirring at $200 \mathrm{rpm}$ for $24 \mathrm{~h}$. At the end of the reduction run, the temperature was increased to $33^{\circ} \mathrm{C}$, while the reaction system was divided into two phases. The products in the organic solvent were collected and analyzed by GC. The biocatalyst in the ILs phase can be separated and recycled by a simple phase separation. The enantiomeric excesses of (R)-EHPB (e.e.(R)) was calculated according to Equation (1):

$$
\text { e.e. }(R)=((R) \text {-EHPB- }(S) \text {-EHPB }) /((R)-\mathrm{EHPB}+(S) \text {-EHPB }) \times 100 \% \text {, }
$$

\subsection{The Pretreatment of Baker's Yeast with Alpha-Phenacyl Chloride}

An amount of $0.4 \mathrm{~g}$ alpha-phenacyl chloride (PC), $50 \mathrm{~mL}$ diethyl ether anhydrous, $1.5 \mathrm{~mL}$ ultrapure water, and $2.5 \mathrm{~g}$ of dry baker's yeast were agitated at $30^{\circ} \mathrm{C}, 200 \mathrm{rpm}$ for $2 \mathrm{~h}$. Subsequently, the pretreated baker's yeast was separated by centrifugation at $4{ }^{\circ} \mathrm{C}$. The residue of PC in yeasts was removed by washing many times with diethyl ether anhydrous until it could not be detected in the final liquid by GC. The pretreated baker's yeast was obtained after drying under a vacuum and stored at $4{ }^{\circ} \mathrm{C}$.

\subsection{Statistical Analysis}

All analyses were carried out in triplicate. The values were described as the means \pm standard deviations. The data were subjected to the analysis of variance (ANOVA) by the Origin program (Origin 9.0). The significance was defined at the 95\% confidence level $(p<0.05)$.

\section{Conclusions}

A new thermosensitive ionic liquids-solvent biphasic system (TIBS) has been built with $c_{2}$ and 1,2-dimethoxyethane, which possesses the thermoregulated function of "mono-phase under low temperature, separation of the system into two phases under high temperature". The phase transformation temperature (PTT) of mixed $c_{2} / 1,2$-dimethoxyethane $(v / v, 5: 18)$ was about $33^{\circ} \mathrm{C}$. This new TIBS was used to the reaction-separation coupling process (RSCP) for the asymmetric reduction of EOPB with baker's yeast. The enantiomeric excesses of ethyl ( $R$ )-EHPB were improved about $25 \sim 30 \%$ and the yield of EHPB was increased 35\% in the thermosensitive biphasic system, compared with that in 1,2-dimethoxyethane. With the pretreated by PC, the reduction activity of baker's yeast and the enantioselectivity of the reduction were improved obviously, shown as the e.e. $(R)$ reached to $48.3 \%$ with the conversion of EOPB and the yield of EHPB significantly increasing to $9 \%$, respectively. In addition, the baker's yeast can be separated and recycled with the biocatalyst activity from the ionic liquid by a single phase separation. It is expected that the new TIBS established in this study could provide many future opportunities in biocatalysis. 
Author Contributions: Y.Y. analyzed the data and drafted the manuscript; Y.S. conceived and designed the experiments and was responsible for raising the funds; S.T. was responsible for the software and resources; L.F. administrated the project and reviewed the manuscript. All authors have read and agreed to the published version of the manuscript.

Funding: This research was supported by the National Natural Science Foundation of China (21106131), Zhejiang Province Public Welfare Technology Application Research Project (LGJ19C200001), Program for Overseas High-Level Experts Introduction (Z20170407), Academic Exchanges and Talent Training Program (2017SICR109), Zhejiang Provincial Food Science and Engineering the Most Important Discipline (JYTsp20142101), Foundation of Zhejiang Provincial Department of Education (Y201737665), and Postdoctoral Fellowships Program of Zhejiang Province ([2017]71-95)

Conflicts of Interest: The authors declare no conflict of interest. The funders had no role in the design of the study; in the collection, analyses, or interpretation of data; in the writing of the manuscript; nor in the decision to publish the results.

\section{Abbreviation}

[BMIM] [PF 6 1-butyl-3-methylimidazolium hexafluorophosphate

DMEA $\quad N, N$-dimethylethanolamine

EHPB ethyl 2-hydroxy-4-phenylbutyrate

e.e. $(R) \quad$ enantiomeric excesses of ethyl (R)-2-hydroxy-4-phenylbutyrate

(R)-EHPB ethyl (R)-2-hydroxy-4-phenylbutyrate

$\mathrm{EO} \quad$ ethylene oxide

EOPB ethyl 2-oxo-4-phenylbutyrate

ESI-MS electron spray ionization mass spectrometry

FT-IR Fourier transform infrared spectroscopy

GC gas chromatography

${ }^{1} \mathrm{H}-\mathrm{NMR} \quad$ proton nuclear magnetic resonance

IL ionic liquid

ILs ionic liquids

PC alpha-phenacyl chloride

PEO polyethylene oxide

PTT phase transformation temperature

RSCP reaction-separation coupling process

THF tetrahydrofuran

TIBS thermosensitive ionic liquids-solvent biphasic system

\section{References}

1. Karakatsani, E.K.; Economou, I.G.; Kroon, M.C.; Bermejo, M.D.; Peters, C.J.; Witkamp, G.J. Equation of state modeling of the phase equilibria of ionic liquid mixtures at low and high pressure. Phys. Chem. Chem. Phys. 2008, 10, 6160-6168. [CrossRef]

2. Montolio-Rodriguez, D.; Linke, D.; Linke, P. Systematic identification of optimal process designs for the production of acetic acid via ethane oxidation. Chem. Eng. Sci. 2007, 62, 5602-5608. [CrossRef]

3. Lin, Y.D.; Chen, J.H.; Cheng, J.K.; Huang, H.P.; Yu, C.C. Process alternatives for methyl acetate conversion using reactive distillation. 1. hydrolysis. Chem. Eng. Sci. 2008, 63, 1668-1682. [CrossRef]

4. Bernal, M.P.; Coronas, J.; Menéndez, M.; Santamaría, J. Coupling of reaction and separation at the microscopic level: Esterification processes in a h-zsm-5 membrane reactor. Chem. Eng. Sci. 2002, 73, 1557-1562. [CrossRef]

5. Irusta, S.; Pina, M.P.; Menéndez, M.; Santamaría, J. Development and application of perovskite-based catalytic membrane reactors. Catal. Lett. 1998, 54, 69-78. [CrossRef]

6. Kraai, G.N.; Schuur, B.; Zwol, F.V.; van de Bovenkamp, H.H.; Heeres, H.J. Novel highly integrated biodiesel production technology in a centrifugal contactor separator device. Biochem. Eng. J. 2009, 154, 384-389. [CrossRef]

7. Maria, P.D. "Nonsolvent" applications of ionic liqulids in biotransformations and organocatalysis. Angew. Chem. Int. Ed. 2008, 47, 6960-6968. [CrossRef] 
8. Garcia, S.; Lourenço, N.M.T.; Lousa, D.; Sequeira, A.F.; Mimoso, P.; Cabral, J.M.S.; Afonso, C.A.M.; Barreiros, S. A comparative study of biocatalysis in non-conventional solvents: Lonic liquids, supercritical fluids and organic media. Green Chem. 2004, 6, 466-470. [CrossRef]

9. Calleri, E.; Temporini, C.; Massolini, G.; Caccialanza, G. Penicillin g acylase-based stationary phases: Analytical applications. J. Pharm. Biomed. Anal. 2004, 35, 243-258. [CrossRef]

10. Massolini, G.; Calleri, E.; De Lorenzi, E.; Pregnolato, M.; Terreni, M.; Felix, G.; Gandinia, C. Immobilized penicillin $\mathrm{g}$ acylase as reactor and chiral selector in liquid chromatography. J. Chromatogr. A 2001, 921, 147-160. [CrossRef]

11. Paiva, A.L.; Malcata, F.X. How performance of integrated systems of reaction and separation relates to that of parallel and sequential configurations. Bioprocess. Eng. 2000, 22, 149-158. [CrossRef]

12. Paiva, A.L.; Malcata, F.X. Integration of reaction and separation with lipases. J. Mol. Catal. B Enzym. 1997, 3 , 99-109. [CrossRef]

13. Habulin, M.; Šabeder, S.; Knez, Ž. Enzymatic synthesis of sugar fatty acid esters in organic solvent and in supercritical carbon dioxide and their antimicrobial activity. J. Supercrit. Fluids. 2008, 45, 338-345. [CrossRef]

14. Šabeder, S.; Habulin, M.; Knez, Ž. Comparison of the esterification of fructose and palmitic acid in organic solvent and in supercritical carbon dioxide. Ind. Eng. Chem. Res. 2005, 44, 9631-9635. [CrossRef]

15. Rekuć, A.; Bryjak, J.; Szymańska, K.; Jarzębski, A.B. Laccase immobilization on mesostructured cellular foams affords preparations with ultra high activity. Process Biochem. 2009, 44, 191-198. [CrossRef]

16. Long, W.S.; Kamaruddin, A.; Bhatia, S. Chiral resolution of racemic ibuprofen ester in an enzymatic membrane reactor. Membr. Sci. 2005, 247, 185-200. [CrossRef]

17. Hernández-Fernández, F.J.; de los Ríos, A.P.; Tomás-Alonso, F.; Gómez, D.; Rubio, M.; Víllora, G. Integrated reaction/separation processes for the kinetic resolution of rac-1-phenylethanol using supported liquid membranes based on ionic liquids. Chem. Eng. Process. 2007, 46, 818-824. [CrossRef]

18. Hernández-Fernández, F.J.; de los Ríos, A.P.; Tomás-Alonso, F.; Gómez, D.; Víllora, G. On the development of an integrated membrane process with ionic liquids for the kinetic resolution of rac-2-pentanol. J. Membr. Sci. 2008, 314, 238-246. [CrossRef]

19. Branco, L.C.; Crespo, J.G.; Afonso, C.A.M. Studies on the selective transport of organic compounds by using ionic liquids as novel supported liquid membranes. Chem. Eur. J. 2002, 8, 3865-3871. [CrossRef]

20. De los Ríos, A.P.; Hernández-Fernández, F.J.; Tomás-Alonso, F.; Rubio, M.; Gómez, D.; Víllora, G. On the importance of the nature of the ionic liquids in the selective simultaneous separation of the substrates and products of a transesterification reaction through supported ionic liquid membranes. J. Membr. Sci. 2008, 307, 233-238. [CrossRef]

21. Hernández-Fernández, F.J.; de los Ríos, A.P.; Rubio, M.; Tomás-Alonso, F.; Gómez, D.; Víllora, G. A novel application of supported liquid membranes based on ionic liquids to the selective simultaneous separation of the substrates and products of a transesterification reaction. J. Membr. Sci. 2007, 293, 73-80. [CrossRef]

22. Scovazzo, P.; Visser, A.E.; Davis, J.H., Jr.; Rogers, R.D.; Koval, C.A.; DuBois, D.L.; Noble, R.D. Noble in Ionic Liquids: Industrial Applications to Green Chemistry; Rogers, R.D., Seddon, K.R., Eds.; American Chemical Society: Washington, DC, USA, 2002; p. 68.

23. Itoh, T. Ionic liquids as tool to improve enzymatic organic synthesis. Chem. Rev. 2017, 117, 10567-10607. [CrossRef] [PubMed]

24. Mori, M.; Garcia, R.G.; Belleville, M.P.; Paolucci-Jeanjean, D.; Sanchez, J.; Lozano, P.; Vaultierc, M.; Riosa, G. A new way to conduct enzymatic synthesis in an active membrane using ionic liquids as catalyst support. Catal. Today 2005, 104, 313-317. [CrossRef]

25. Ha, S.H.; Lan, M.N.; Lee, S.H.; Hwang, S.M.; Koo, Y.M. Lipase-catalyzed biodiesel production from soybean oil in ionic liquids. Enzyme Microb. Technol. 2007, 41, 480-483. [CrossRef]

26. Guo, Z.; Xu, X. Lipase-catalyzed glycerolysis of fats and oils in ionic liquids: A further study on the reaction system. Green Chem. 2006, 8, 54-62. [CrossRef]

27. Schlosser, Š.; Kertész, R.; Marták, J. Recovery and separation of organic acids by membrane-based solvent extraction and pertraction: An overview with a case study on recovery of mpca. Sep. Purif. Technol. 2005, 41, 237-266. [CrossRef]

28. Fang, S.; Xie, H.J.; Chen, H.Y.; Wang, L.; Tian, S.Y. Solute-solvent interactions of amino acid, l-phenylalanine in aqueous 1-butyl-2,3-dimethylimidazolium bromide ionic liquid solutions. J. Chem. Thermodyn. 2017, 113, 144-150. [CrossRef] 
29. Park, S.; Kazlauskas, R.J. Biocatalysis in ionic liquids-advantages beyond green technology. Curr. Opin. Biotechnol. 2003, 14, 432-437. [CrossRef]

30. Kong, F.; Jiang, J.; Jin, Z. Ammonium salts with polyether-tail: New ionic liquids for rhodium catalyzed two-phase hydroformylation of 1-tetradecene. Catal. Lett. 2004, 96, 63-65. [CrossRef]

31. Shi, Y.G.; Wu, Y.; Lu, X.Y.; Ren, Y.P.; Wang, Q.; Zhu, C.M.; Yu, D.; Wang, H. Lipase-catalyzed esterification of ferulic acid with lauryl alcohol in ionic liquids and antibacterial properties in vitro against three food-related bacteria. Food Chem. 2017, 220, 249-256. [CrossRef] [PubMed]

32. Shao, S.Y.; Shi, Y.G.; Wu, Y.; Bian, L.Q.; Zhu, Y.J.; Huang, X.Y.; Pan, Y.; Zeng, L.Y.; Zhang, R.R. Lipase-catalyzed synthesis of sucrose monolaurate and its antibacterial property and mode of action against four pathogenic bacteria. Molecules 2018, 23, 1118. [CrossRef] [PubMed]

33. Baldwin, R.L. How hofmeister ion interactions affect protein stability. Biophys. J. 1996, 71, $2056-2063$. [CrossRef]

34. De, D.; Lozano, P.; Lozano, P.; Abad, M.; Steffensky, K.; Vaultier, M.; Iborra, J.L. On the nature of ionic liquids and their effects on lipases that catalyze ester synthesis. J. Biotechnol. 2009, 140, 234-241. [CrossRef]

35. Pedro, L.; Rungtiwa, P.; Kevin, K.; Teresa, D.D.; Michel, V.; Jose' L, I. Ionic liquids improve citronellyl ester synthesis catalyzed by immobilized Candida antarctica lipase B in solvent-free media. Green Chem. 2007, 9, 780-784. [CrossRef]

36. Mattias, P.; Uwe T, B. Increased stability of an esterase from Bacillus stearothermophilus in ionic liquids as compared to organic solvents. J. Mol. Catal. B-Enzym. 2003, 22, 21-27. [CrossRef]

37. Roxana, I.; Katsuya, K. Lipase-catalyzed enantioselective reaction of amines with carboxylic acids under reduced pressure in non-solvent system and in ionic liquids. Tetrahedron Lett. 2004, 45, 523-525. [CrossRef]

38. Gutiérrez-Ayesta, C.; Carelli, A.A.; Ferreira, M.F. Relation between lipase structures and their catalytic ability to hydrolyse triglycerides and phospholipids. Enzym. Microb. Tech. 2007, 41, 35-43. [CrossRef]

39. Kaar, J.K.; Jesionowski, A.M.; Berberich, J.A.; Moulton, R.; Russell, A.J. Impact of Ionic Liquid Physical Properties on Lipase Activity and Stability. J. Am. Chem. Soc. 2003, 125, 4125-4131. [CrossRef]

40. Turner, M.B.; Spear, S.K.; Huddleston, J.G.; Holbrey, J.D.; Rogers, R.D. Ionic liquid salt-induced inactivation and unfolding of cellulase from Trichoderma reesei. Green Chem. 2003, 5, 443-447. [CrossRef]

41. Van Rantwijk, F.; Sheldon, R.A. Biocatalysis in Ionic Liquids. Chem. Rev. 2007, 107, 2757-2785. [CrossRef]

42. Itoh, T.; Akasaki, E.; Kudo, K.; Shirakami, S. Lipase-catalyzed enantioselective acylation in the ionic liquid solvent system: Reaction of enzyme anchored to the solvent. Chem. Lett. 2001, 30, 262-263. [CrossRef]

43. Zhao, H.; Baker, G.A.; Song, Z.; Olubajo, O.; Crittle, T.; Peters, D. Designing enzyme-compatible ionic liquids that can dissolve carbohydrates. Green Chem. 2008, 10, 696-705. [CrossRef]

44. Zhao, H.; Jones, C.L.; Cowins, J.V. Lipase dissolution and stabilization in ether-functionalized ionic liquids. Green Chem. 2009, 11, 1128-1138. [CrossRef]

45. Zhao, H.; Jones, C.L.; Baker, G.A.; Xia, S.; Olubajo, O.; Person, V.N. Regenerating cellulose from ionic liquids for an accelerated enzymatic hydrolysis. J. Biotechnol. 2009, 139, 47-54. [CrossRef] [PubMed]

46. Rasalkar, M.S.; Potdar, M.K.; Salunkhe, M.M. Pseudomonas cepacia lipase-catalysed resolution of racemic alcohols in ionic liquid using succinic anhydride: Role of triethylamine in enhancement of catalytic activity. J. Mol. Catal. B Enzym. 2004, 27, 267-270. [CrossRef]

47. Yang, Z.; Pan, W. Ionic liquids: Green solvents for nonaqueous biocatalysis. Enzym. Microb. Technol. 2005, 37, 19-28. [CrossRef]

48. Shi, Y.G.; Fang, Y.; Ren, Y.P.; Guan, H.L.; Zhang, J.Y. Applying alpha-phenacyl chloride to the enantioselective reduction of ethyl 2-oxo-4-phenylbutyrate with baker's yeast. J. Chem. Technol. Biotechnol. 2008, 84, 681-688. [CrossRef]

Sample Availability: Samples of the novel thermosensitive ionic liquids are available from the authors. 